\title{
Journal Prices, Book Acquisitions, and Sustainable College Library Collections
}

\section{William H. Walters}

\begin{abstract}
Library collections are economically sustainable only if the rate of increase in costs is no greater than the rate of increase in the library acquisitions budget. Because book prices increase at a much lower rate than journal prices, undergraduate libraries can achieve economic sustainability through a renewed emphasis on books rather than journals. Book-centered collections are consistent with the goals of many undergraduate colleges, and books rather than journals may provide the best teaching resources even in those fields that rely heavily on journals for the communication of original research results.
\end{abstract}

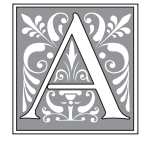

sustainable library collection is one that can be maintained without significant degradation over time-one with a budget that provides for continued access to serial resources (journal subscriptions and online databases) as well as the timely acquisition of important monographic materials (books, media, and other onetime purchases). In general terms, an economically sustainable collection is one for which the rate of increase in prices is no greater than the rate of increase in the library acquisitions budget. As this essay shows, most academic library collections are not economically sustainable under current conditions. For many undergraduate libraries, the most reliable way to achieve sustainability is through (1) a renewed emphasis on books rather than journals; (2) the evaluation of journals and online resources using systematic procedures that account for both quality of content and sustainability of access; and (3) an open-minded but cautious approach to new information formats, new pricing models, and new mechanisms for scholarly communication.

\section{Book and Journal Prices}

Books, rather than journals, have traditionally been regarded as the core of the academic library collection. For most of the twentieth century, journals and other subscriptions accounted for less than a third of library acquisitions expenditures at most colleges and universities. ${ }^{1}$ As Charles Hamaker has noted, "except in pure science and medical collections, serials were almost an afterthought." 2

A major shift in priorities occurred at most research libraries in the early 1980s,

William H. Walters is Dean of Library Services and Associate Professor of Social Sciences at Menlo College in Atherton, California; e-mail: wwalters@menlo.edu. He is grateful for the advice and assistance of Cheryl Collins, Bart Harloe, Megan O'Malley, Esther Isabelle Wilder, David Zubatsky, and two anonymous referees. 
when aggregate serials expenditures exceeded book expenditures for the first time. ${ }^{3}$ At undergraduate libraries, the transition occurred later, typically in the mid-1990s. ${ }^{4}$ By 2000, the primacy of journal collections was well established in most academic libraries. Both undergraduate and research libraries now devote 70 to 80 percent of their acquisitions budgets to print and online serials. ${ }^{5}$ Because the decline in library book acquisitions has coincided with an increase in scholarly book production, academic libraries are able to purchase only a small and diminishing proportion of the important new books published each year. ${ }^{6}$

This shift in expenditure patterns can be attributed mainly to rising journal prices, especially in the sciences. Unfortunately, librarians have had at least two immediate incentives to place a higher priority on journals than on books. First, journal subscriptions are almost always regarded as ongoing financial commitments. The cancellation of a long-standing subscription is often viewed as a sign of poor collection management, since librarians, faculty, and students all tend to assume that new journal subscriptions will be continued indefinitely. Second, journal cancellations are bound to elicit a negative reaction from the faculty, while cuts in the book budget are more likely to slip by unnoticed. As a past president of the American Library Association has noted, the book budget is often "what is left over when all the other materials budgets are determined."7 The high priority given to journals has had a major impact on libraries' expenditure patterns. Among American research libraries, serials expenditures increased by 302 percent from 1986 to 2005. In contrast, monograph expenditures increased by only 59 percent during that time-a rate lower than the cumulative increase in the Consumer Price Index (78 percent). ${ }^{8}$

The diversion of funds from the book budget to the serials budget is an effective method of delaying journal cancellations. At the same time, this strategy poses a serious long-term problem: it reduces

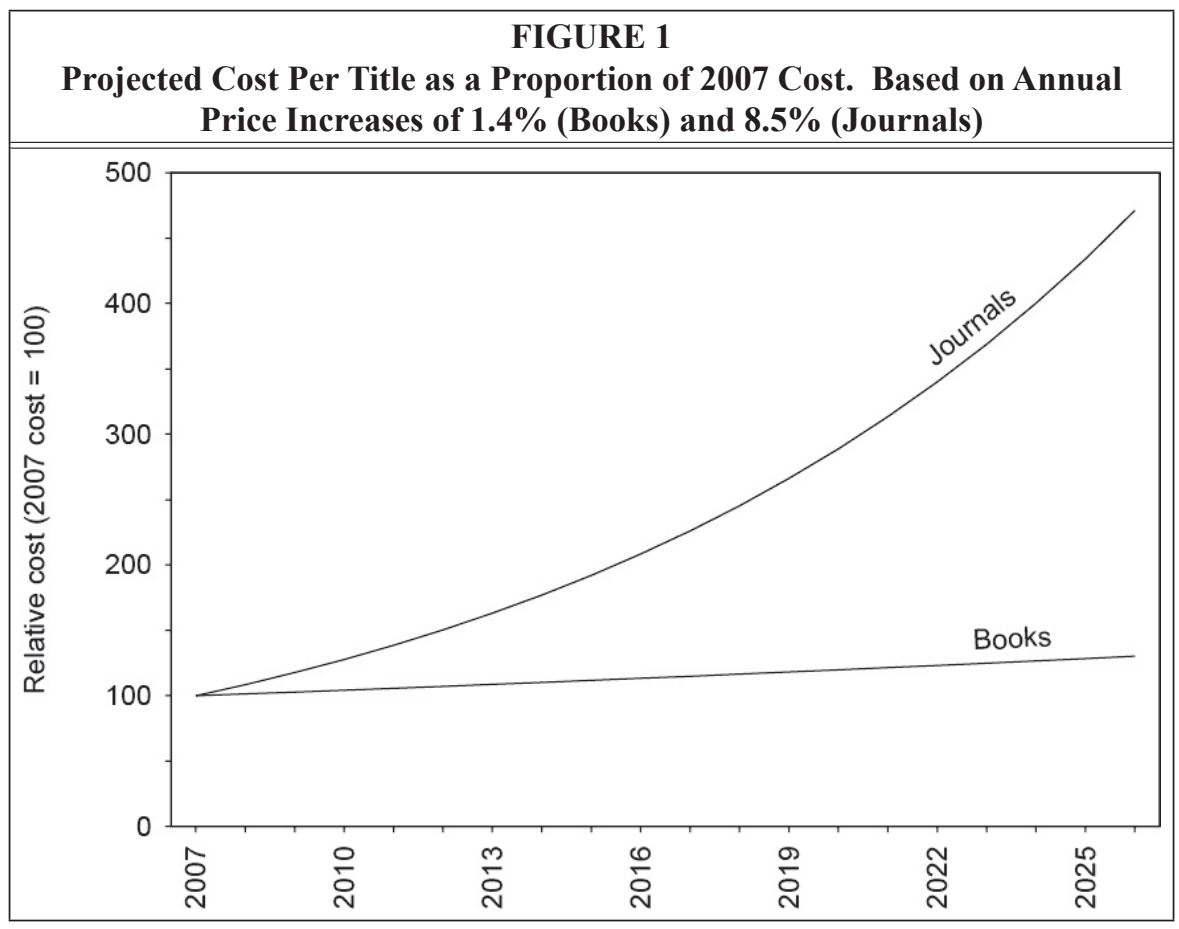


the economic sustainability of the library collection as a whole. Specifically, it increases the library's commitment to that portion of the collection for which prices are increasing most rapidly. While the annual inflation rate for academic books is just 1.4 percent, the rate for academic periodicals (both print and online) is 8.5 percent. ${ }^{9}$ (Although a switch from print to online format can produce significant one-time savings, it does little to reduce the rate of increase in costs. The average annual rate of increase for full-text databases and journal packages is 7.2 percent, just slightly lower than the rate for single-title subscriptions. ${ }^{10}$ Applying current inflation rates over a twenty-year period, we can see dramatic differences in the projected costs of books and journals (figure 1).

Relatively few faculty or administrators realize the extent of the problem, which can be demonstrated most clearly through a hypothetical example. ${ }^{11}$ Envision a situation in which the entire library acquisitions budget is devoted to periodical subscriptions. With journal price increases of 8.5 percent per year and budget increases of 3.0 percent, the number of journal subscriptions will decline by more than 60 percent over a twenty-year period. In contrast, a library collection devoted primarily to books is far more sustainable in economic terms. With book price increases of 1.4 percent and budget increases of 3.0 percent, a library that spent its entire acquisitions budget on books would be able to purchase 35 percent more books in 2026 than in 2007 (figure 2).

The more libraries spend on journals, the greater the number of journal cancellations that will be required in the future. Long-term access to the scholarly literature may therefore depend, at least partly, on the maintenance or restoration of libraries' support for books-on investing in that portion of the collection that is most economically sustainable. A renewed emphasis on book collections

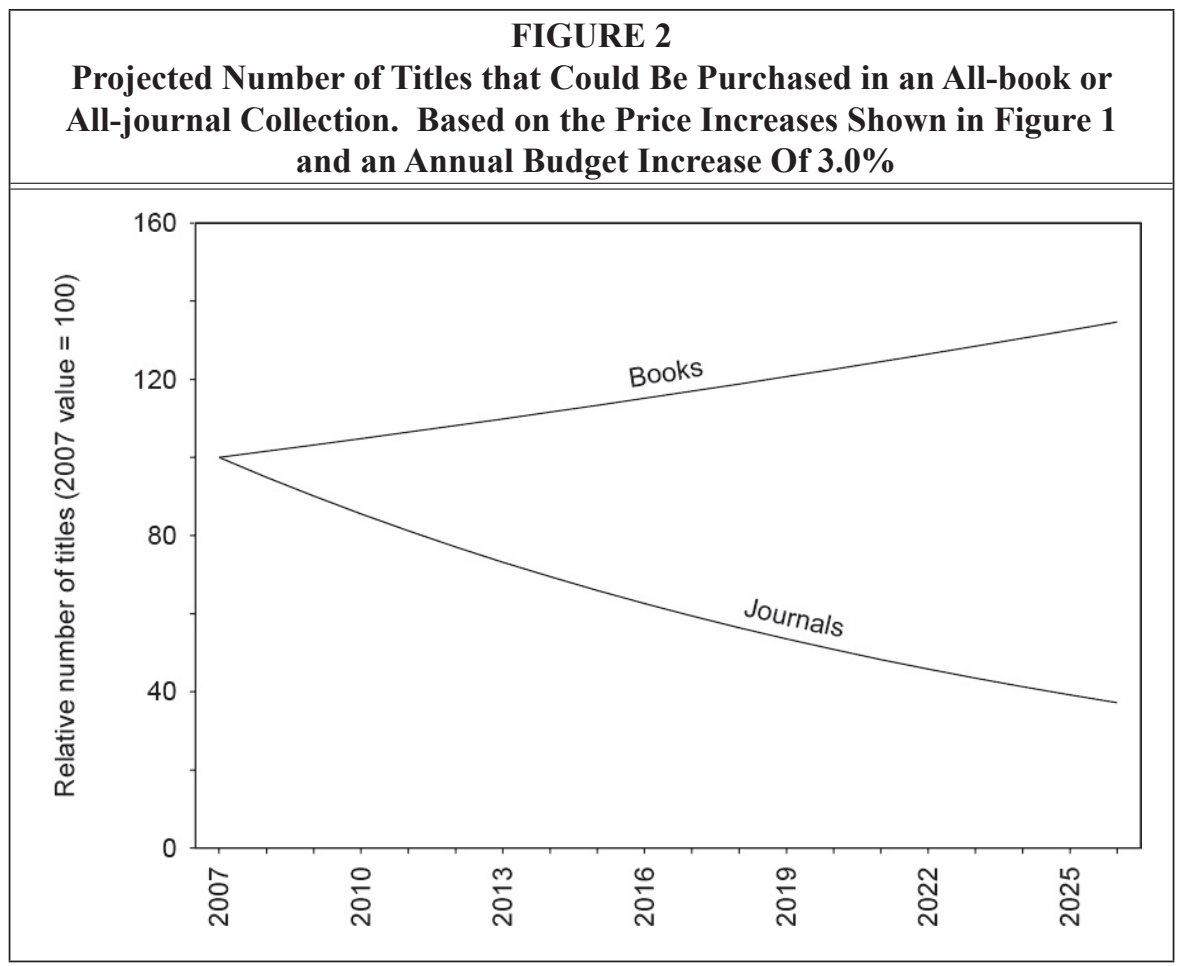


might also help support nonprofit publishers and ultimately provide a greater number of outlets for scholarly work. According to the Modern Language Association, the decline in book purchases by academic libraries is the single most important factor in the financial problems facing university presses. ${ }^{12}$

\section{Books in the Undergraduate College}

Obviously, the large-scale cancellation of current journal subscriptions is not feasible for certain kinds of academic institutions. After all, the ultimate goal of the library is to support teaching and scholarship-not to minimize costs. Research universities are therefore unlikely to reduce their reliance on journals, which account for virtually all of the new research published in the natural sciences.

At the same time, the development of a sustainable, book-centered library collection may be appealing to many undergraduate colleges. There are at least four reasons for this. First, many undergraduate colleges were relatively late in making the transition from bookcentered collections to journal-centered collections. In some cases, a renewed emphasis on books would merely restore the priorities that prevailed until recent years - the priorities that many faculty are still familiar with. Second, undergraduate colleges tend to have relatively low acquisitions budgets and fewer external funding options. They are therefore more likely to face serious financial problems sooner rather than later. For most, the question is not whether to reduce journal spending, but whether to do it earlier (through a coordinated long-term plan that helps build a strong book collection) or later (on an ad hoc basis in response to immediate budgetary pressures). Third, faculty at even the best undergraduate colleges publish far fewer papers than those at research universities. For example, Grinnell College has $1 / 25$ as many faculty as the University of Michigan but produces $1 / 300$ as many journal articles. ${ }^{13}$
Undergraduate faculty are therefore less likely to require immediate access to the latest research. Although the research literature is undoubtedly important for undergraduate teaching, interlibrary loan may be an acceptable substitute for immediate access at many undergraduate institutions. Finally, colleges are more likely to have a teaching mission that gives special priority to the kinds of library resources that are most valuable to undergraduates. In many cases, that means books rather than journals. For example, the Great Books curriculum at St. John's College is supported by a library that devotes nearly four-fifths of its acquisitions budget to monographs. As a result, combined book and serials expenditures at St. John's are far lower than the average for all baccalaureate institutions. ${ }^{14}$

Admittedly, a library collection with relatively few journal subscriptions cannot provide immediate access to the full range of scientific research. At the same time, books rather than journals provide the best way for many students to gain familiarity with the ideas and evidence used in the sciences. While the journal literature of biochemistry (for example) is unintelligible to many undergraduates, books in that same subject area may be exactly what students need. As Juris Dilevko and Lisa Gottlieb have demonstrated, undergraduates tend to prefer books for several reasons: their authoritativeness and comprehensiveness, their readability, their emphasis on fundamental facts and theories, and their inclusion of contextual information that may not be readily available in articles. In Dilevko and Gottlieb's survey of undergraduates at the University of Toronto, the "use of print books was typically associated with the production of high-quality work."15 Students favored other resources chiefly when they needed to complete their assignments as quickly as possible.

Moreover, recent research shows that students and faculty in the sciences use 
library books just as much as their counterparts in the humanities. For example:

- library books in the natural and applied sciences typically circulate just as much as those in other subject areas; ${ }^{16}$

- the use of electronic books (views or downloads per title) is higher in the sciences than in other fields, ${ }^{17}$

- engineering and physical science majors check out library books only slightly less often than other students; ${ }^{18}$

- nursing students rely more on books than on journals, ${ }^{19}$

- in their written coursework, engineering students beyond the first year of study cite five times as many books as journal articles; ${ }^{20}$

- science faculty cite books on a regular basis, and the number of citations per cited book is especially high in the sciences; ${ }^{21}$

- more than 80 percent of the books acquired by academic health science libraries circulate within the first three years, with an average of 4.6 circulations during that time.22

Circulation data for a typical liberal arts college (table 1) provide further evidence of frequent book use in the sciences. In particular, book circulation is well above average in many of the same scientific fields for which journal prices are highest. This suggests that the development of a strong book collection does not necessarily lead to a bias in favor of the humanities. Additional research is needed before we can reach a firm conclusion, however. For example, we do not know the extent to which books can replace journals as instructional resources for students in particular scientific fields. Although the available evidence shows that undergraduates in the sciences rely heavily on the monographic literature, we do not know the extent to which that literature provides comprehensive coverage of all scientific subjects. Further investigation might reveal, for instance, that human biology is well represented in current academic books but that low-temperature physics is not.

\begin{tabular}{|c|c|}
\hline \multicolumn{2}{|c|}{$\begin{array}{c}\text { TABLE } 1 \\
\text { Average Annual Circulation, by } \\
\text { Subject Area }\end{array}$} \\
\hline Literature (English and American) & 2.07 \\
\hline Bibliography and related fields & 1.90 \\
\hline Mathematics & 1.64 \\
\hline Chemistry & 1.46 \\
\hline Psychology & 1.33 \\
\hline History & 1.22 \\
\hline Biology & 1.08 \\
\hline Political science & 1.15 \\
\hline Geography and anthropology & 1.14 \\
\hline Music & 1.08 \\
\hline Physics & 1.05 \\
\hline Education & 1.03 \\
\hline Philosophy & 1.00 \\
\hline Social sciences (general) & 1.00 \\
\hline Engineering and technology & 0.98 \\
\hline Languages and linguistics & 0.93 \\
\hline Law & 0.91 \\
\hline General works & 0.86 \\
\hline $\begin{array}{l}\text { Literature (not English or Ameri- } \\
\text { can) }\end{array}$ & 0.84 \\
\hline Fine arts & 0.75 \\
\hline Religion & 0.72 \\
\hline Geology & 0.58 \\
\hline Astronomy & 0.43 \\
\hline Military and naval science & 0.39 \\
\hline Natural sciences (general) & 0.33 \\
\hline $\begin{array}{l}\text { Note: Includes all books cataloged } \\
\text { and } 2005 \text { at St. Lawrence Universi }\end{array}$ & 2004 \\
\hline
\end{tabular}

\section{Strategies for Sustainability}

Three related strategies can help undergraduate colleges build and maintain sustainable library collections.

\section{Emphasize books rather than journals}

In the current environment, the most reliable method of ensuring sustainability is to buy more books and fewer journals. Unfortunately, this strategy is often overlooked in the search for new and exciting 
ways to deal with the serials crisis. For instance, the former president of a major information technology and policy organization has argued that sustainability depends at least partly on the transfer of journal ownership from commercial publishers to scholarly societies and other nonprofit organizations. ${ }^{23}$ In making that assertion, he barely mentions academic book publishing, the one area of scholarly communication in which nonprofit publishers have played a dominant role for the past several decades.

Of course, libraries exist not only as collections, but as organizations that support the multiple and sometimes contradictory goals of higher education. Consequently, libraries must align their collection policies and fund allocation strategies with the priorities of their parent institutions. For many university libraries, the recommendation to buy more books and fewer journals is simply inconsistent with the need to support a high level of sustained research activity. At the same time, a renewed focus on book purchasing may help many college libraries bring their collections into closer alignment with the requirements of undergraduate instruction. As it stands, even the most influential books can be found in relatively few college libraries. Consider Choice magazine's Outstanding Academic Titles, for example. Each year, Choice's expert reviewers and editors select approximately 700 new books in accordance with six criteria: "overall excellence in presentation and scholarship, importance relative to other literature in the field, distinction as a first treatment of a given subject in book or electronic form, originality or uniqueness of treatment, value to undergraduate students, and importance in building undergraduate library collections." ${ }^{24}$ These 700 books include just one of every 540 academic titles published in the United States and Britain. While not every book on the list is appropriate for every undergraduate library, many institutions that offer a full range of degree programs hold rela- tively few of the Outstanding Academic Titles. For example, the typical public college in Pennsylvania acquires just 31 percent of the Outstanding Academic Titles published each year. ${ }^{25}$ Very few librarians would argue that such meager holdings are consistent with high-quality instruction.

Librarians and faculty committed to building sustainable library collections must first realize that rising journal expenditures result from explicit or implicit policy decisions made at the institutional level. Increased spending on journals is not inevitable, nor can it be attributed solely to external forces acting on the library or the college. For example, the cost control strategies adopted by some of the largest public libraries are markedly different from those that prevail at most colleges and universities. Public libraries in the largest U.S. cities tend to respond to increasing prices or declining budgets by purchasing fewer periodicals rather than fewer book titles. ${ }^{26}$

\section{Evaluate journals and online resources using systematic procedures that account for both quality of content and sustainability of access}

Access to the journal literature is essential for undergraduate research in the natural and social sciences. Students also appear to be relying more heavily on journal articles in recent years, perhaps in response to the widespread availability of full-text databases. ${ }^{27} \mathrm{At}$ the same time, an undergraduate journal collection need not be extensive in order to include a high proportion of the articles that students are most likely to need. Contrary to what is sometimes taught in library instruction classes, the best scholarship on a particular topic is unlikely to appear in journals devoted solely to that topic. After all, major new developments in stem cell research will be reported in Nature, Science, or Cellnot in specialized journals that focus on stem cell research. Specialized journals tend to have lower scholarly impact and 
to be less attractive as outlets for highquality work. ${ }^{28}$

In fact, the most important research tends to be concentrated in a relatively small number of key journals. The 56 organic chemistry journals covered by Journal Citation Reports were cited more than 450,000 times in 2006. More than half those citations were to the top four journals in the field. In applied physics, four of the 84 journals account for half the citations. ${ }^{29}$ Because influential journals often have high circulation, they also tend to charge less for institutional subscriptions. For instance, Annals of Mathematics has nearly 1,600 subscribers, a citation impact factor of 2.0, and an annual list price of $\$ 265$. In contrast, a typical specialized math journal, Fundamenta Informaticae, has just 300 subscribers, an impact factor of 0.3 , and a list price of $\$ 1,560 .^{30}$

Although multidisciplinary full-text databases provide access to thousands of periodicals, relatively few of those titles are top-tier scholarly journals. Many are newspapers, magazines, and publications of local or ephemeral interest. Others are journals of lesser stature that aim to increase their readership by licensing content to full-text database vendors. As a consequence, many libraries struggle to fund databases that do little to improve students' access to high-quality research. At one Pennsylvania college, the number of highly ranked journals (current issues held) has declined over the past decade despite a nearly ten-fold increase in the overall number of periodical titles available to students. In 1995, the college held 37 percent of the high-impact journals in 55 key subject areas. By 2006, that figure had dropped to 35 percent. $^{31}$

Sustainability of access to individual resources is another important consideration when building a journal collection. While preservation refers to the continued availability of an information resource to the scholarly community in general, sustainable access refers to the availability of that resource to the faculty and students at a particular institution. ${ }^{32}$ Sustainable access is the norm for print journals, since any volumes received during the subscription period are retained by the library even after the subscription is cancelled. The acquisition of a print journal entails the permanent purchase of content as well as the right to use that content in particular ways: to lend, sell, and copy it within the Fair Use and Educational Use provisions of copyright. In contrast, most license agreements for online resources are actually lease agreements that provide for access only during the years in which the subscription fee has been paid. Leased online access is therefore a risky proposition, since it makes sustainability of access contingent on sustainability of payments. In relying on leased access, libraries are essentially betting that they will have the funds to continue paying for those resources every year. Leased access to full-text databases makes libraries susceptible to loss of content in the event of a one-year budget shortfall or a publisher's decision to withdraw its journals from a particular database.

For online resources, the most important aspect of sustainable access is licensing-specifically, license agreements that give the library perpetual access to the content published during the license period, along with any necessary access mechanisms or interfaces. The most favorable licensing terms will also address issues such as changes in technology and changes in corporate ownership of the licensed material. A small but growing number of online resource providers are beginning to recognize the importance of license agreements that allow for sustainable access. ${ }^{33}$ In many cases, however, license agreements must be regarded as temporary lease agreements rather than long-term investments in the library collection. Unless license terms are carefully monitored (and perhaps negotiated), the large-scale replacement of print subscriptions with online resources reduces the proportion of journals for which sustainable access can be assured. 


\section{Maintain an open-minded but cautious approach to new information formats, new pricing models, and new mechanisms for scholarly communication}

The approach to sustainability outlined here is essentially conservative. It is based on the assumption that the institutional framework of scholarly communication will remain more or less intact-that technological advances, however impressive, will not alter the basic economic, cultural, and legal underpinnings of the current system. This assumption may or may not be valid, however, and future developments are likely to bring both opportunities and challenges. A commitment to the development of sustainable library collections therefore requires an open-minded but cautious approach to new information formats, new pricing models, and new mechanisms for scholarly communication. For example, Portico offers a promising model of third-party support for digital archives - the same kinds of archives that many libraries would establish for themselves if they had the necessary resources. ${ }^{34}$ (Portico makes arrangements with publishers to serve as a long-term archive for content, then prepares and maintains that content in accordance with established standards.) Nonetheless, Portico's approach to sustainable access has not yet proven economically feasible over time. Likewise, Open Access journals have the potential to make scientific research more accessible than ever before, but only if the most productive research institutions (and, by extension, their funding agencies) are willing and able to pay a higher proportion of the total systemwide cost. ${ }^{35}$

New initiatives, however promising, must themselves prove sustainable. Unfortunately, not all successful pilot projects can be maintained over an extended period, on a large scale, or when faced with economic or legal challenges. The safest plan is to support well-founded new initiatives while simultaneously working to promote sustainability through more conventional means.

\section{Future Directions}

Unfortunately, the strategy that best promotes economic sustainability for particular libraries is unlikely to be effective in reducing costs for the higher education sector as a whole. Among other things, the large-scale cancellation of specialized journals would presumably increase prices for the remaining subscribers and perhaps even threaten the sustainability of the journal publishing system. The cancellation of journal subscriptions remains an effective course of action for individual libraries only because the benefit accrues to a particular college or university while the cost (the potential increase in journal prices) is shared among a much larger number of institutions.

Looking beyond the needs of individual libraries, we encounter a more basic question: Why is the inflation rate for books so much lower than that for journals? Ideally, we would be able to identify the characteristics of book publishing that result in stable prices, then work to promote those same characteristics in the journal literature-all while maintaining the qualities that have made journals so successful in the first place: timeliness, transparency of peer review, and an article format well-suited to the process of scientific research. If high journal prices result solely from high demand for research in journal-centric disciplines, then the serials cost crisis may indeed be intractable. On the other hand, high prices may reflect the relatively minor role played by nonprofit journal publishers in certain scientific and technical fields. In that case, scholarly societies and other nonprofits may be able to help address the problem of rising journal costs.

Another important distinction between books and journals is the degree to which content is bundled for sale. For books other than edited collections, the item offered for purchase is a single scholarly work. In contrast, most journals bundle together multiple works (articles) that vary in topic, quality, and impact. ${ }^{36}$ Journal publishers are able to charge high 
prices at least partly because libraries are willing to pay for articles they don't need to gain access to those they do need. Bundling also occurs on a larger scale, when publishers or vendors group multiple journals into online collections or full-text databases.

Fortunately, the online environment offers mechanisms that facilitate the disaggregation or unbundling of journal content-mechanisms that may help college libraries reduce their costs by purchasing only the articles they need. The difficulties with this proposal are economic rather than technical, since most publishers have no incentive to adopt a marketing strategy that is likely to reduce their revenue. It is possible that the disaggregation of journal content will be achieved only when publishers realize that their less important journals are no longer attractive to undergraduate institutions under the current pricing model-when colleges cancel their subscriptions in favor of more economically sustainable forms of scholarly communication.

\section{Notes}

1. David Kaser, "Collection Building in American Universities," in University Library History: An International Review, ed. James Thompson (New York: K.G. Saur, 1980), 33-55; Charles B. Osburn, Academic Research and Library Resources: Changing Patterns in America (Westport, Conn.: Greenwood Press, 1979).

2. Charles Hamaker, "The Place of Scholarly and Scientific Libraries in an Increasingly and More Widespread Competitive Information Knowledge Marketplace," in Scholarly Publishing: Books, Journals, Publishers, and Libraries in the Twentieth Century, ed. Richard E. Abel and Lyman W. Newlin (New York: Wiley, 2002), 279.

3. Anna H. Perrault, "The Shrinking National Collection: A Study of the Effects of the Diversion of Funds from Monographs to Serials on the Monograph Collections of Research Libraries," Library Acquisitions: Practice \& Theory 18, no. 1 (Spring 1994): 3-22.

4. Based on data for Millersville University (Millersville, Pennsylvania) and St. Lawrence University (Canton, New York).

5. Martha Kyrillidou and Mark Young, ARL Statistics, 2004-05 (Washington, D.C.: Association of Research Libraries, 2006), available online at www.arl.org/bm doc/arlstat05.pdf [accessed 2 March 2008]; Alan MacDougall, “University Libraries: The Lull Before the Storm?” Bookseller no. 4437 (Jan. 4, 1991): 20, 22.

6. Andrew Grabois, "Book Title Output and Average Prices: 2004 Final and 2005 Preliminary Figures," in The Bowker Annual: Library and Book Trade Almanac 2006, ed. Dave Bogart (Medford, N.J.: Information Today, 2006), 516-22; Perrault, "The Shrinking National Collection"; Charles A. Schwartz, "Modeling Scholarly Book Literature," Publishing Research Quarterly 10, no. 2 (Summer 1994): 29-35.

7. Michael Gorman, "The Economic Crisis in Libraries: Causes and Effects," in Scholarly Publishing: Books, Journals, Publishers, and Libraries in the Twentieth Century, ed. Richard E. Abel and Lyman W. Newlin (New York: Wiley, 2002), 266.

8. Kyrillidou and Young, ARL Statistics, 2004-05.

9. Book data are for North American academic books, 2001-2005. Periodicals data include both U.S. and foreign titles, 2003-2006, and reflect the purchasing patterns of both undergraduate and research libraries. EBSCO Information Services, Serials Prices 2002-2006 with Projections for 2007 (Birmingham, Ala.: EBSCO Information Services, 2006), available online at www.ebsco. com/home/printsubs/priceproj.asp [accessed 16 November 2007]; Janet Belanger Morrow, "Prices of U.S. and Foreign Published Materials," in The Bowker Annual: Library and Book Trade Almanac 2006, ed. Dave Bogart (Medford, N.J.: Information Today, 2006), 495-515.

10. Comprehensive, national data on the prices of online databases and journal collections are not available. The rate presented here, 7.2 percent, is based on local data for St. Lawrence University and Millersville University - specifically, on an analysis of changes in the invoice prices of those resources that were renewed from 2004 to 2005 and from 2005 to 2006.

11. Similar scenarios have been described by at least four authors: Gorman, "The Economic Crisis in Libraries"; Brian L. Hawkins, "The Unsustainability of the Traditional Library and the Threat to Higher Education," in The Mirage of Continuity: Reconfiguring Academic Information Resources for the 21st Century, ed. Brian L. Hawkins and Patricia Battin (Washington, D.C.: Council on Library and Information Resources, 1998), 129-53; Joseph J. Kohut, "Allocating the Book Budget: 
A Model," College E Research Libraries 35, no. 3 (May 1974): 192-99; Charles B. Osburn, "Marketing the Collection Development Aspects of Serials Control," in Serials Collection Development: Choices and Strategies, ed. Sul H. Lee (Ann Arbor, Mich.: Pierian Press, 1981), 9-17.

12. MLA Ad Hoc Committee on the Future of Scholarly Publishing, "The Future of Scholarly Publishing," in Profession 2002 (New York: Modern Language Association, 2002), 172-86. Available online at www.mla.org/pdf/schlrlypblshng.pdf. [Accessed 2 March 2008].

13. Based on data for journal articles in the fields of general biology, cell biology, organic chemistry, and applied physics. William H. Walters, "Institutional Journal Costs in an Open Access Environment," Journal of the American Society for Information Science and Technology 58, no. 1 (Jan. 1, 2007): 108-20.

14. National Center for Education Statistics, 2004 Academic Libraries Survey (Washington, D.C.: National Center for Education Statistics, 2006). Available online at http://nces.ed.gov/surveys/libraries/compare/Index.asp?LibraryType=Academic. [Accessed 2 March 2008].

15. Juris Dilevko and Lisa Gottlieb, "Print Sources in an Electronic Age: A Vital Part of the Research Process for Undergraduate Students," Journal of Academic Librarianship 28, no. 6 (Nov. 2002): 391.

16. Jennifer E. Knievel, Heather Wicht, and Lynn Silipigni Connaway, "Use of Circulation Statistics and Interlibrary Loan Data in Collection Management," College E Research Libraries 67, no. 1 (Jan. 2006): 35-49.

17. Marilyn Christianson, "Patterns of Use of Electronic Books," Library Collections, Acquisitions, E Technical Services 29, no. 4 (Dec. 2005): 351-63.

18. Ethelene Whitmire, “Disciplinary Differences and Undergraduates' Information-Seeking Behavior," Journal of the American Society for Information Science and Technology 53, no. 8 (June 2002): 631-38.

19. Cheryl Dee and Ellen E. Stanley, "Information-Seeking Behavior of Nursing Students and Clinical Nurses: Implications for Health Sciences Librarians," Journal of the Medical Library Association 93, no. 2 (Apr. 2005): 213-22.

20. Fei Yu, Jan Sullivan, and Leith Woodall, "What Can Students' Bibliographies Tell Us? Evidence Based Information Skills Teaching for Engineering Students," Evidence Based Library and Information Practice 1, no. 2 (2006): 12-22.

21. Nisa Bakkalbasi and David Goodman, "Do Science Researchers Use Books?" in Charleston Conference Proceedings 2004, ed. Rosann Bazirjian, Vicky Speck, and Beth R. Bernhardt (Westport, Conn.: Libraries Unlimited, 2006), 55-62.

22. Deborah D. Blecic, "Monograph Use at an Academic Health Sciences Library: The First Three Years of Shelf Life," Bulletin of the Medical Library Association 88, no. 2 (Apr. 2000): 145-51. Also see Jonathan D. Eldredge, "The Vital Few Meet the Trivial Many: Unexpected Use Patterns in a Monographs Collection," Bulletin of the Medical Library Association 86, no. 4 (Oct. 1998): 496-503.

23. Hawkins, "The Unsustainability of the Traditional Library."

24. American Library Association, Outstanding Academic Titles (Chicago: American Library Association, 2006). Available online at www.ala.org/ala/acrl/acrlpubs/choice/outstanding/academic. htm. [Accessed 2 March 2008].

25. This value, correct as of March 2006, is the average for 13 of the 14 colleges in the Pennsylvania State System of Higher Education - all those for which data were available. The analysis is based on a random sample of 100 Outstanding Academic Titles published from 2000 through 2004.

26. William C. Robinson, "Price of Materials and Collection Development in Larger Public Libraries," Library Acquisitions: Practice \& Theory 19, no. 3 (Fall 1995): 299-312.

27. Reba Leiding, "Using Citation Checking of Undergraduate Honors Thesis Bibliographies to Evaluate Library Collections," College E Research Libraries 66, no. 5 (Sept. 2005): 417-29.

28. See, for example, Sophie L. Wilkinson, "Behind the Scenes at Journals," Chemical E Engineering News 77, no. 37 (Sept. 13, 1999): 25-31.

29. Institute for Scientific Information, Journal Citation Reports. These examples illustrate Bradford's Law, which is supported by extensive evidence. Samuel C. Bradford, "Sources of Information on Specific Subjects," Engineering 137, no. 4 (Jan. 26, 1934): 85-86.

30. CSA, Ulrich's Periodicals Directory (Bethesda, Md.: CSA, 2007); Institute for Scientific Information, Journal Citation Reports.

31. This finding, for Millersville University, is based on a random sample of 100 high-impact journals in the natural and social sciences. High-impact journals were defined as those ranked among the top 15 journals, in terms of citedness (impact factor), in each of 55 subject areas commonly taught at undergraduate colleges. While not all high-impact journals are appropriate for undergraduate students, impact factor is the most widely accepted indicator of overall journal quality. See Institute for Scientific Information, Journal Citation Reports (Philadelphia: Thomson Scientific, 2007). 
32. William H. Walters, "Criteria for Replacing Print Journals with Online Journal Resources: The Importance of Sustainable Access," Library Resources \& Technical Services 48 , no. 4 (Oct. 2004): 300-04.

33. Links to the license agreements used by nearly 350 publishers and vendors can be found at EBSCO Information Services, Publishers' License Agreements (Birmingham, Ala.: EBSCO Information Services, 2007). Available online at http://ejournals.ebsco.com/ejournals/license.asp. [Accessed 2 March 2008].

34. Ithaka Harbors, Portico: An Electronic Archiving Service (New York: Ithaka Harbors, 2006). Available online at www.portico. org/about/portico_brochure.pdf. [Accessed 2 March 2008].

35. Walters, "Institutional Journal Costs in an Open Access Environment"; William H. Walters and Esther Isabelle Wilder, "The Cost Implications of Open Access Publishing in the Life Sciences," BioScience 57, no. 7 (July/Aug. 2007): 619-25.

36. Per O. Seglen, "Causal Relationship Between Article Citedness and Journal Impact," Journal of the American Society for Information Science 45, no. 1 (Jan. 1994): 1-11.

\section{www.hedgehogreview.com}

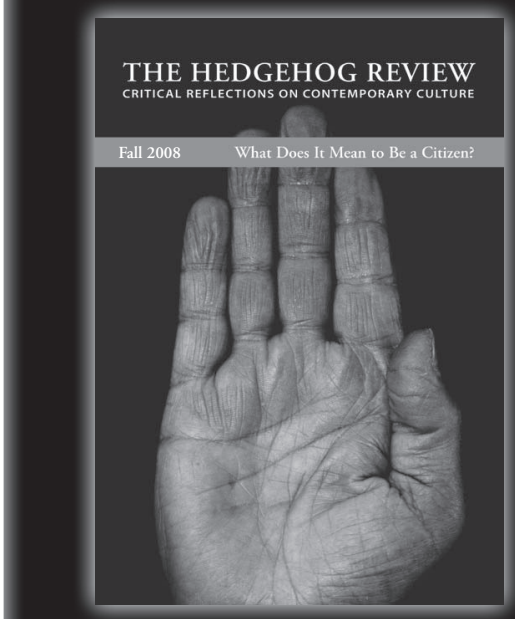

The Hedgehog Review is an awardwinning journal of critical reflections on contemporary culture containing essays, reviews, and more.

Just $\$ 40 /$ year will put us on your shelf. 